\title{
PRICE LEVEL CONVERGENCE AND INFLATION IN EUROPE
}

\author{
John H. Rogers \\ Senior Economist, International Finance Division, \\ Federal Reserve Board \\ Gary Clyde Hufbauer \\ Reginald Jones Senior Fellow, \\ Institute for International Economics \\ Erika Wada \\ Research Assistant, \\ Institute for International Economics
}

The authors present direct evidence on price level convergence in Europe, using a unique data set. They then investigate how much of the recent differences in national inflation rates in the euro area can be explained by faster rising prices in the low-cost euro countries (i.e. by price level convergence within Europe). Between 1990 and 1999, prices became less dispersed in the euro area. Convergence was especially evident for traded goods, more in the first half of the 1990s than the second half. For tradables, price dispersion in the euro area has fallen into the range found in the United States. While price level convergence contributed to observed inflation differences within the euro area, other forces explain most of the current cross-country differences in euro area inflation.

The authors thank Jon Faust, Joe Gagnon, Mike Gilbert, Chris Gust, Dale Henderson, Jane Ihrig, Karen Johnson, Steve Kamin, David Kobuszewski, and Vince Reinhart for their suggestions. 


\section{INTRODUCTION}

Consumer price inflation in the euro area declined steadily during most of the 1990s. However, in the last two years, both headline and core inflation have risen throughout the area, and sizable cross-country differences in inflation have re-emerged. This is illustrated by Figure 1, which shows the headline consumer price inflation rate for the euro area as a whole and for select member countries. As of October 2000, all euro area countries had headline inflation rates above the European Central Bank's 2 percent medium-term ceiling, with rates ranging from 2.1 percent in France and Austria to 6 percent in Ireland. In Greece, which will join the euro area on 1 January 2001, inflation was 3.8 percent.

One factor, discussed prominently in policymaking circles, that may be contributing to crosscountry differences in inflation is price level convergence or "inflation catch-up". 1 According to the argument, if prices expressed in a common currency are initially different across countries, convergence to a common level of prices implies higher inflation in countries where prices are initially low. There are several reasons to expect at least some price convergence in Europe. Progress toward a single market, including already completed trade liberalization and adoption of the single currency, should narrow differences in common-currency prices across countries, at least for traded goods. To the extent that the currency conversion rates chosen at the launch of the euro did not equate price levels across the euro area, scope remained for further price convergence after January 1999.

The Balassa-Samuelson hypothesis provides another explanation why prices of nontraded goods might rise faster in poorer European countries. ${ }^{2}$ Suppose that poor countries are initially low-price countries, and that economic integration creates pressure for European-wide convergence of productivity levels in making traded goods. In addition, suppose that productivity levels in making nontraded goods converge at a much slower rate, if at all. Under these assumptions, poor countries will find that their productivity growth is concentrated in the traded goods sector. The rise in output and wages in the traded goods sector that would result from a European-wide convergence of productivity, would then push up wages and hence prices in the nontraded goods sector of the poor countries, compared to the wealthier, high-price countries.

\footnotetext{
${ }^{1}$ See ECB President Wim Duisenberg's 6 September 2000 speech “Are Different Price Developments in the Euro Area a Cause for Concern?", http://www.ecb.int/, or "Inflation Differentials in a Monetary Union," in the Monthly Bulletin of the European Central Bank, October 1999, 36-44.

2 Pelkmans, Gros and Ferrer (2000) provide a very useful exposition of the Balassa-Samuelson hypothesis.
} 
Thus, either under the "more perfect union" rationale, or under the Balassa-Samuelson rationale, countries with initial low prices could be expected to experience relatively high inflation following increased economic integration.

To the extent that the price level convergence hypothesis applies to Europe, some of the current divergence of inflation rates in the euro area may simply be transitory, part of the move toward a common

price level in the region. ${ }^{3}$ The hypothesis also suggests that as the euro area widens to include Greece and, potentially, other relatively low-price countries in Eastern Europe, inflation rates in the new member nations could rise substantially.

In this paper, evidence on the price level convergence hypothesis is presented using a unique data set of prices across European cities. ${ }^{4}$ It is found, first, that between 1990 and 1999, price levels became less dispersed in the euro area. This convergence was especially evident for traded goods, and was stronger in the first half of the 1990s than the second half. Second, it is shown that, although price level convergence is a significant factor in explaining current cross-country differences in euro area inflation, other forces provide a more important explanation.

\section{THE DATA}

There is no ready source of data on aggregate price levels (the cost of a common basket of goods) for the countries in this study. Therefore, as described in the Appendix, the indexes of price levels had to be constructed from price data on 165 goods and services in 26 cities $^{5}$ in 18 countries-all 11 members of the euro area, 6 other West European nations, and Israel. The raw price data are collected annually in the spring by the Economist Intelligence Unit (EIU), which calculates cost-of-living indexes for multinational corporations that move employees around the world. Data from 1990, 1995, and 1999 are analyzed in this paper. The EIU survey teams are instructed to record local prices of tightly specified goods such as 1 kilogram of white bread, 1 liter of Coca-Cola, a tube of toothpaste, a pair of blue jeans, and services such as "woman's haircut and blow dry (tips included)" and rent on unfurnished apartments of 5 to 6 rooms.

\footnotetext{
${ }^{3}$ However, to the extent that price level convergence occurs through the relatively gradual process of convergence of productivity and living standards, the resulting cross-country inflation differentials may be long-lived.

4 The data are also used by Hufbauer, Wada, and Warren (2000) to estimate the welfare improvement that would accompany a convergence of prices worldwide.

5 The cities are Amsterdam, Athens, Barcelona, Madrid, Berlin, Dusseldorf, Frankfurt, Hamburg, Munich, Brussels, Copenhagen, Dublin, Geneva, Zurich, Helsinki, London, Lisbon, Luxembourg, Lyon, Paris, Milan, Rome, Oslo, Stockholm, Tel Aviv, and Vienna.
} 
The entire sample of goods and services is listed in Appendix Table A.1. Although all goods have both tradable and nontradable components, we designate the service-type items as "nontradable" and consider the rest to be "tradable". The local-currency prices reported by the EIU are converted to US dollars at the market exchange rate prevailing at the time of the survey.

To construct a price index from the raw data, we assign each of the 165 items to one of the 12 two-digit categories comprising the European harmonized indexes of consumer prices (listed in Table A.1). Prices are weighted equally within these categories. Because consumption patterns differ across countries, different sets of country-specific weights are used. The weights are listed in Appendix Table A.2. The resulting indexes are normalized to make the mean for all cities taken together equal to 1 each year. Thus, a price level of 0.91 for Dublin implies that overall 1999 prices in that city were 9 percent lower than in the average city. Separately, an analogous sample of prices in 14 US cities $^{6}$ is analyzed. Because the United States has long been a functioning monetary union, the results serve as a useful basis of comparison with Europe.

\section{PRICE LEVEL CONVERGENCE}

Table 1 presents direct evidence on price convergence during the 1990s, both within the euro area and within the United States. The standard deviation of prices across locations, a measure of price dispersion, is reported for three years (1990, 1995 and 1999) and for three different price indexes (overall (all 165 items), traded goods, and nontraded goods).

As seen in the top half of Table 1, there was a slight decline in overall price dispersion over the full period within the euro area, with the standard deviation falling from 0.12 in 1990 to 0.10 in 1999 . For tradables, there was much stronger evidence of convergence, especially in the first half of the 1990s - a period that includes the major liberalization of trade in goods and movement of factors of production. Our measure of dispersion of traded goods prices fell by more than one-half over the 1990s. Unsurprisingly, there is much more dispersion of nontradables prices than tradables prices, and no evidence of convergence for nontradables over the decade.

As shown in the lower half of Table 1, there is little evidence of an ongoing process of price convergence across US cities. Even for tradables, our measure of dispersion barely budged over the decade, falling from 0.04 in 1990 to 0.03 in 1999. Table 1 also indicates that traded goods prices have been more equal within the United States than within the euro area, especially early in the decade. This probably reflects the long-standing absence in the United States of policy restrictions on trade in goods or

6 Atlanta, Boston, Chicago, Cleveland, Detroit, Honolulu, Houston, Los Angeles, Miami, New York, Pittsburgh, San Francisco, Seattle, and Washington, DC. 
factor mobility. However, the dispersion of traded goods prices in the euro area is now quite close to that in the United States. Prices of non-tradeables have been less equal across the United States than the euro area, mostly due to the much greater dispersion of housing prices across US cities. ${ }^{7}$ Nontradables prices show little tendency to converge over time.

\section{INFLATION IN EUROPE}

The evidence on price convergence in the euro area implies a negative relationship between initial price levels and subsequent inflation during the 1990s. Additional evidence indicates that this relationship is also present in more recent data. The scatter plot of 18 countries in Figure 2 relates 1999 price levels (shown on the horizontal axis) to the 4-quarter 2000Q3 rate of inflation in those countries (shown on the vertical axis). The pattern shows that recent rates of headline consumer price inflation are indeed higher in countries that had relatively low prices in $1999 .{ }^{8}$ This result is very robust to alternative measures of inflation such as consumer price inflation excluding energy and inflation of the GDP deflator. It also holds in an analysis of 1995 price levels and inflation rates in subsequent years.

Table 2 presents cross-country regressions to determine whether the negative correlation between current inflation and 1999 price levels remains important, once additional variables that also influence inflation are taken into account. The dependent variable in these regressions is the country's 4-quarter rate of consumer price inflation in 2000Q3. Explanatory variables include the 1999 price level, real GDP growth rate, output gap, and dollar value of per capita real GDP relative to the United States. ${ }^{9}$ The growth rate of real GDP is included in the regression to capture possible "speed-limit effects" on inflation, which may be important independent of the customary effects of the output gap, even though the two explanatory variables are highly correlated. Relative per capita GDP in 1999 is included to account for the tendency for low-price countries to be relatively poor as well. In addition, openness to non-EU trade in 1999 is considered. This is measured as total merchandise trade (exports plus imports) with the rest of the

7 The weight on housing in the overall US price index is 30 percent, amounting to about one-half of the nontradables index. The weight on housing in any country of the euro area is no larger than Germany's 20.8 percent. See Table A. 2 for the full set of weights.

${ }^{8}$ As shown in the scatter plot, the correlation between the initial price level and subsequent inflation for the 11 euro area countries is -0.66 . The negative correlation also holds true for inflation rates in October 2000 , the most recent available inflation rate as of this writing. We use the 2000Q3 Figures because they are less affected by temporary blips than the monthly rates. All results in this section are robust to the choice of inflation number, however.

${ }^{9}$ The Appendix lists the sources of our data. 
world less total trade with other members of the European Union, as a share of GDP. This variable is designed to capture relative exposure to inflation imported from abroad, either directly or through the effects of the weak euro. ${ }^{10}$

As indicated in Table 2 (line 1), the correlation between current inflation and the 1999 price level is negative and significant. Business cycle effects, initial income levels, and openness to non-EU trade are also important determinants of inflation. Column 1 shows the findings for the euro area countries alone. Column 2 indicates that the negative correlation between current inflation and 1999 price level is also large for the full sample of 18 countries, 7 of them outside the euro area.

Column 3 shows results for an analysis of inflation excluding energy prices. The sample includes the 11 countries within the euro area, as in the first regression. The notable differences, relative to the findings in column 1, are the increased importance of 1999 GDP growth (its effect on inflation, excluding energy, is nearly double its effect on headline inflation), and the decreased importance of openness. This is just as expected: "domestic" factors like GDP growth have a relatively large effect on core inflation rates, while the "external" factors proxied by our openness measure (the weak euro, oil, or other import price changes) have a relatively large effect on energy prices and hence headline inflation. Finally, measures of productivity growth and tax rates are also added to the regressions. These variables generally had no effect on the results, and so are not shown.

The regressions provide evidence on the economic importance of the 1999 price level in explaining current inflation divergence. The coefficient of -5.27 in column 1 implies that a country whose 1999 price level was 10 percent lower than the average would have an inflation rate in 2000Q3 of about one-half percentage point higher than a country with the average 1999 price level. The regressions in columns 2 and 3 have similar implications. In addition, as indicated at the bottom of the Table, the 1999 price level explains between 7 to 13 percent of the cross-country variation in inflation within the euro area, (columns 3 and 1, respectively), and 22 percent in the full sample of 18 countries (column 2).

To gain a sense of the importance of price convergence relative to the other explanatory variables, it is instructive to consider Ireland. In 2000Q3, Irish headline inflation was almost 3 percentage points above average. Recalling that Ireland's price level was 9 percent below average in 1999, the regression estimates imply that price level convergence accounts for nearly 0.5 percentage points of the deviation of current Irish inflation from the European average. The estimates in column 1 also imply that Ireland's rapid GDP growth rate in 1999—6 percentage points above the euro area average of 3.8 percent — pushed Irish inflation 1.5 percentage points above average in 2000Q3. Moreover, Ireland is the most open of the

\footnotetext{
${ }^{10}$ Measures of productivity growth and tax rates were also considered in the regressions. These variables generally had no effect on the results, and so are not shown.
} 
euro area countries to non-EU trade. The model in column 1 implies that this contributed 0.7 percentage points to Ireland's above average inflation rate in 2000Q3.

Thus, a rough decomposition of Ireland's divergent inflation performance indicates that just over one percentage point is due to "international factors" (price level convergence and openness) that are beyond the influence of Irish policymakers. However, 1.6 percentage points are due to conventional "national" factors (GDP growth and the output gap) that are affected by domestic policy. A counterfactual decomposition using the column 1 estimates for Greece, a poor and low-price country relative to euro area averages, reveals that price level convergence would push inflation a full percentage point above the euro area average, while business cycle effects would have a relatively small influence.

\section{SUMMARY}

Price level convergence has been put forth by prominent policymakers as a potential explanation for inflation divergence in the euro area. It is likely to be a greater policy concern in the future, as enlargement of the euro area brings full membership to Greece next month and, potentially, to other relatively low-price countries such as the Czech Republic, Estonia, Hungary, Poland, and Slovenia perhaps as early as 2004. Our research provides evidence of an ongoing process of price level convergence in the euro area. Price convergence has contributed to observed inflation differences, but other forces explain most of the cross-country differences in inflation. Finally, the scope for further price convergence among current members of the euro area appears limited, as the dispersion of tradables prices in the area is now quite similar to that in the United States. 


\section{REFERENCES}

Balassa, Bela. (1964). The Purchasing Power Parity Doctrine: A Re-Appraisal, Journal of Political Economy, 72, 584-596. December.

Hufbauer, Gary, Erika Wada, and Tony Warren. (2000). The Benefits of Price Convergence. Washington: Institute for International Economics. Photocopy.

Pelkmans, Jacques, Daniel Gros, and Jorge Nunez Ferrer. (2000). Long-Run Economic Aspects of the European Union's Eastern Enlargement, WRR Scientific Council for Government Policy, The Hague.

Samuelson, Paul. (1964). "Theoretical Notes on Trade Problems," Review of Economics and Statistics, 64, 145-154. May. 
Figure 1 Euro area headline inflation rates

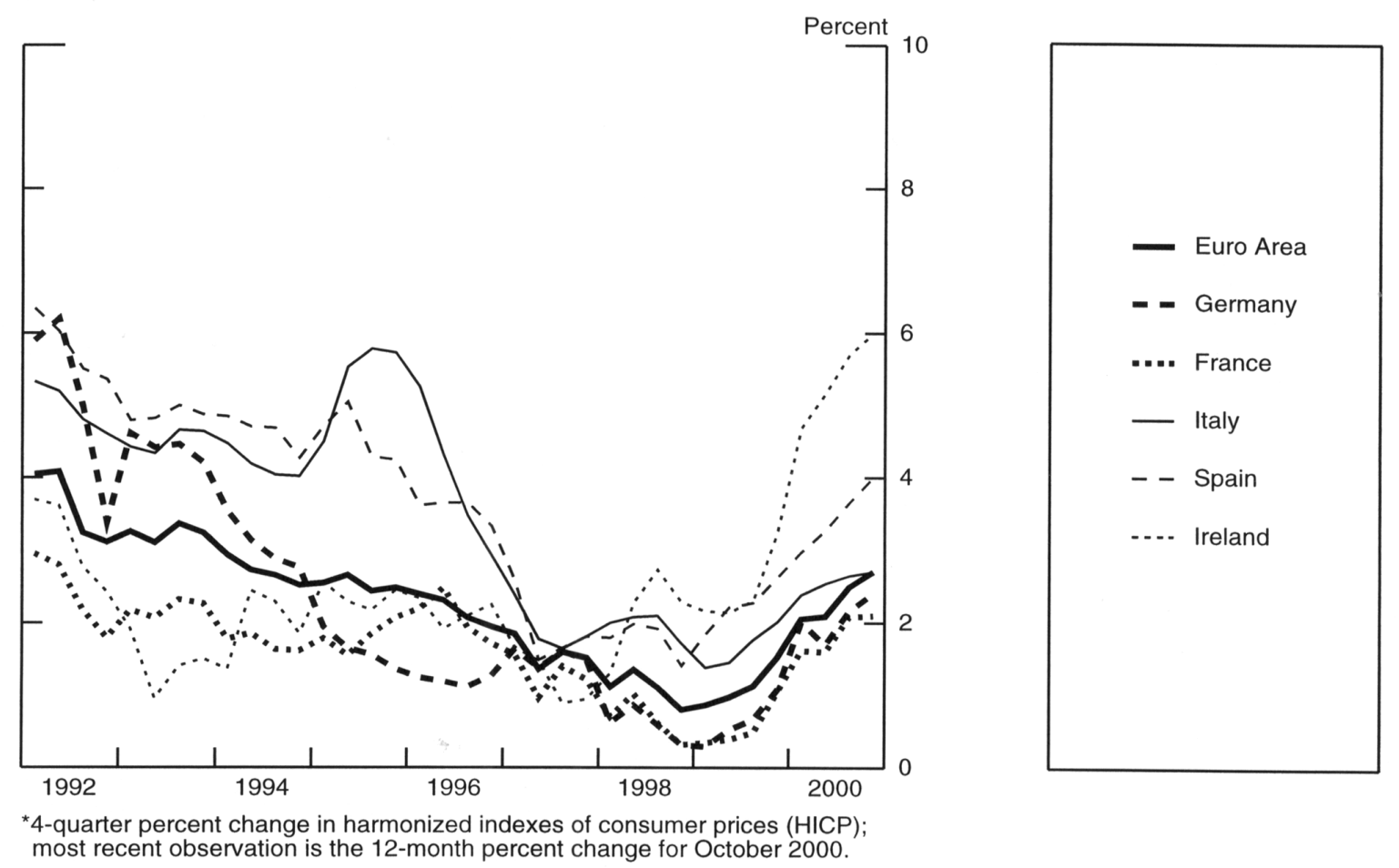

Table 1 How much have prices in the euro area converged?

\begin{tabular}{llccc}
\hline & & \multicolumn{3}{c}{$\begin{array}{c}\text { Standard deviation of prices } \\
\text { across locations }\end{array}$} \\
\cline { 3 - 4 } Euro area & Price index & $\mathbf{1 9 9 0}$ & $\mathbf{1 9 9 5}$ & $\mathbf{1 9 9 9}$ \\
& Overall & 0.12 & 0.12 & 0.10 \\
& Tradables & 0.11 & 0.07 & 0.05 \\
Nontradables & 0.26 & 0.32 & 0.28 \\
& Overall & & 0.14 & 0.16 \\
& Tradables & 0.15 & 0.03 & 0.03 \\
& Nontradables & 0.51 & 0.49 & 0.56 \\
\hline
\end{tabular}


Figure 22000 inflation versus 1999 price level

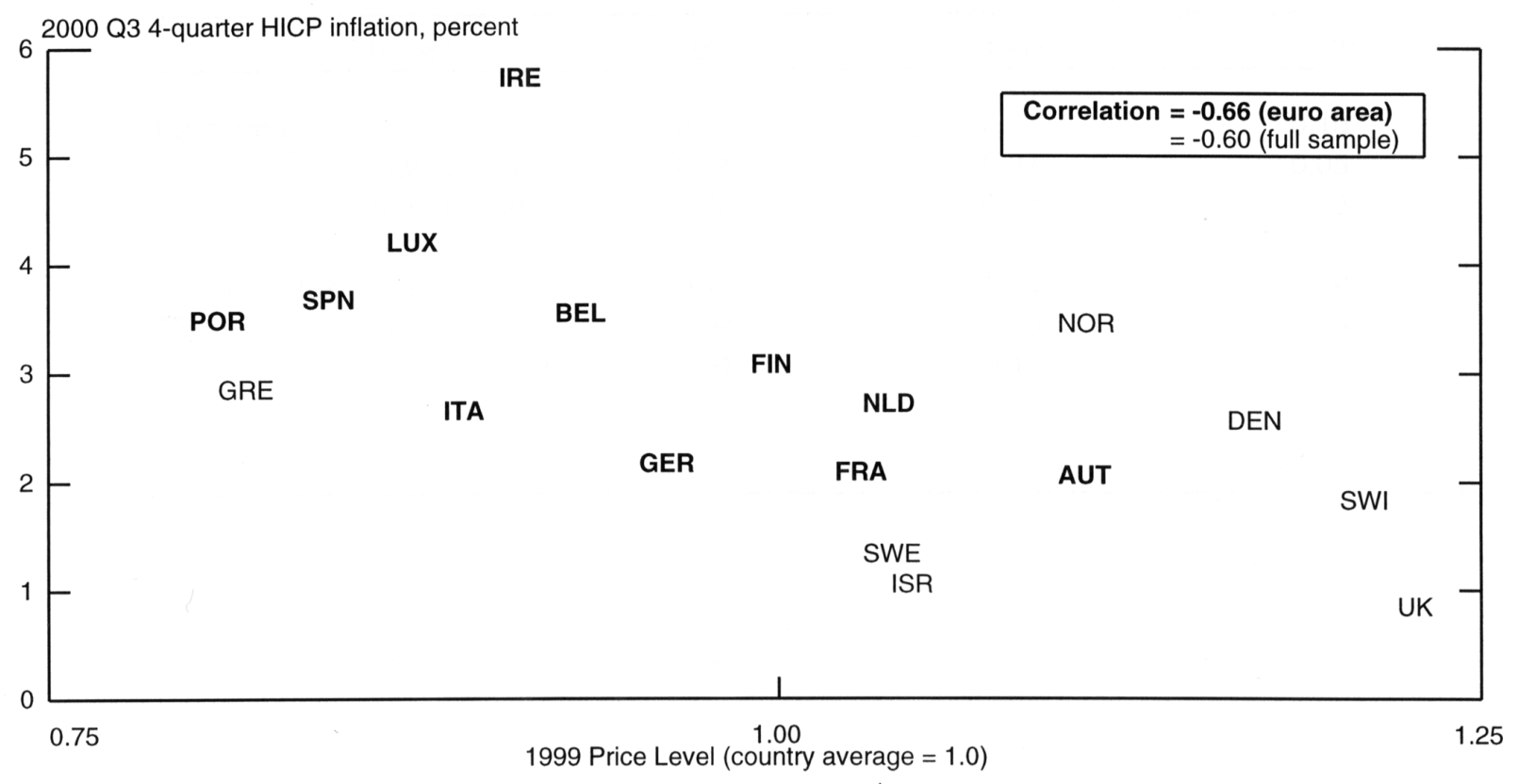

Table 2 Explaining inflation in Europe

\begin{tabular}{lccc}
\hline & $\begin{array}{c}(\mathbf{1}) \\
\text { Euro area }\end{array}$ & $\begin{array}{c}\mathbf{( 2 )} \\
\text { Full }\end{array}$ & $\begin{array}{c}\mathbf{( 3 )} \\
\text { sample } \\
\text { Euro area } \\
\text { (excluding } \\
\text { energy) }\end{array}$ \\
\hline Price level, 1999 & -5.27 & -6.09 & -4.20 \\
GDP growth, 1999 & $(-6.30)$ & $(-6.28)$ & $(-2.98)$ \\
& 0.24 & -0.02 & 0.42 \\
Output gap, 1999 & $(4.74)$ & $(-0.15)$ & $(8.56)$ \\
Relative per capita & 0.08 & 0.40 & -0.03 \\
GDP, 1999 & $(0.99)$ & $(3.65)$ & $(-0.19)$ \\
Openness to non-EU trade, & -0.58 & 2.28 & -3.88 \\
1999 & $(-2.14)$ & $(2.10)$ & $(-14.6)$ \\
& 3.05 & 3.02 & 0.80 \\
& $(3.90)$ & $(2.08)$ & $(0.89)$ \\
Adjusted R-squared & & & 0.87 \\
Inflation variation explained & $13 \%$ & & $7 \%$ \\
by 1999 price level & & 0.65 & \\
Number of countries in & 11 & $22 \%$ & 11 \\
sample & & & \\
\hline HICP = Harmonized indexes of consumer prices. & & & \\
Notes: Dependent variable: 2000 Q3 4-quarter HICP inflation; t-statistics are in parentheses; a constant is \\
included in all regressions.
\end{tabular}




\section{APPENDIX A CONSTRUCTION OF THE PRICE INDEXES}

The raw price data from the EIU sample of goods and services, listed in Table A.1, is used to construct an index as close as possible conceptually to the national consumer price index. The price of each good in each of the 26 cities is divided by the average price of that particular good across all cities. Then the \$lemeaned\#prices are weighted to construct the price index for location $\mathrm{k}, p_{k}{ }^{w}$, as:

$$
p_{k}^{w}=\frac{1}{165} \sum_{i=1}^{165} \alpha_{i k}\left(\frac{p_{i k}}{\frac{1}{26} \sum_{k=1}^{26} p_{i k}}\right)
$$

where the goods are weighted equally within categories of the European harmonized indexes of consumer prices (HICP), using the country-specific weights listed in Table A.2.

\section{APPENDIX B \\ DATA SOURCES}

HICP inflation rates and GDP growth rates were taken from the Eurostat database. Per capita GDP relative to the United States was obtained from the IMF's World Economic Outlook database, www.imf.org. The merchandise imports and exports used to construct the openness measures were obtained from the IMF's Direction of Trade Statistics database. The output gaps are from staff estimates in the International Finance Division of the Federal Reserve Board. 
Table A.1 List of goods and services

\begin{tabular}{|c|c|}
\hline Food and nonalcoholic beverages (CPO1) & Nesquick chocolate powder (500 grams) \\
\hline Bread, white (100 grams) & Orange juice ( 1 liter) \\
\hline Butter (500 grams) & Tea (25 bags) \\
\hline Cheese, imported (500 grams) & Tonic water ( 0.2 liter) \\
\hline \multicolumn{2}{|l|}{ Cornflakes (375 grams) } \\
\hline Flour, white (1000 grams) & Alcoholic beverages and tobacco (CP02) \\
\hline Margarine (500 grams) & Beer, local brand ( 1 liter) \\
\hline Milk, canned, condensed (397 grams) & Beer, top quality ( 0.33 liter) \\
\hline Milk, pastuerized (1 liter) & Gin, Gilbey's or equivalent ( 0.7 liter) \\
\hline Olive oil (1 liter) & Imported French VSOP cognac \\
\hline Peanut or corn oil (1liter) & Liqueur Cointreau (0.7 liter) \\
\hline Rice, white (1000 grams) & Vermouth, Martini Rossi (1 liter) \\
\hline Spaghetti (1000 grams) & Whiskey, Scotch six years old ( 0.7 liter) \\
\hline Sugar, white (1000 grams) & Wine, common table ( 1 liter) \\
\hline Yogurt & Wine, fine quality ( 1 liter) \\
\hline Apples (1000 grams) & Wine, superior quality ( 1 liter) \\
\hline Bananas (1000 grams) & Cigarettes, local brand (pack of 20) \\
\hline Carrots (1000 grams) & Cigarettes, Marlboro (pack of 20) \\
\hline Eggs (per dozen) & Pipe tobacco, MacBaren (50 grams) \\
\hline \multicolumn{2}{|l|}{ Lemons (1000 grams) } \\
\hline Lettuce (per head) & Clothing and footwear (CP03) \\
\hline Mushrooms & Dry cleaning, man's suit $(\mathrm{N})$ \\
\hline Onions (1000 grams) & Dry cleaning, trousers $(\mathrm{N})$ \\
\hline Oranges (1000 grams) & Dry cleaning, ladies' dress $(\mathrm{N})$ \\
\hline Potatoes (2000 grams) & Laundry (one shirt) \\
\hline Tomatoes (1000 grams) & Business, shirt white \\
\hline Green beans ( 250 grams) & Business suit, two-piece med. weight \\
\hline Peaches (500 grams) & Cardigan sweater \\
\hline Peas (250 grams) & Dress, ready to wear, daytime \\
\hline Sliced pineapples (500 grams) & Raincoat, Burberry type \\
\hline Tomatoes (250 grams) & Shoes, business wear \\
\hline Beef roast (1 kilo) & Shoes, town \\
\hline Beef, steaks entrecotes (1 kilo) & Socks, wool mixture \\
\hline Beef, stewing shoulder (1 kilo) & Tights, pantyhose \\
\hline Beef, filet mignon (1 kilo) & Boy's dress, blazer \\
\hline Beef, ground or minced (1 kilo) & Boy's dress trousers \\
\hline Veal chops (1 kilo) & Boy's jacket \\
\hline Veal filets (1 kilo) & Girl's dress \\
\hline Veal roast ( 1 kilo) & Jeans \\
\hline Lamb chops (1 kilo) & Shoes, dresswear \\
\hline Leg of lamb (1kilo) & Shoes, playwear \\
\hline \multicolumn{2}{|l|}{ Lamb stews (1 kilo) } \\
\hline Bacon (1 kilo) & Housing, water, and electricity (CP04) \\
\hline Pork chops (1 kilo) & Furnished apartments, 3-room (1 bedroom) (N) \\
\hline Pork loin (1 kilo) & Furnished apartments, 4-room (2 bedrooms) (N) \\
\hline Whole ham ( 1 kilo) & Furnished apartments, luxury (N) \\
\hline Chicken, fresh (1 kilo) & Unfurnished apartments, 4-room (2 bedrooms) (N) \\
\hline Chicken, frozen (1 kilo) & Unfurnished apartments, 5-6-room \\
\hline Fresh fish ( 1 kilo) & ( 3 bedrooms) $(\mathrm{N})$ \\
\hline Frozen fish filets or fingers ( 1 kilo) & Unfurnished apartment, 7-9-room (4 bedrooms) (N) \\
\hline Cola drink (1 liter) & Annual estimate of utility costs: 3 -bedroom house \\
\hline Cocoa (500 grams) & (excl. phone) (N) \\
\hline Ground coffee (500 grams) & Annual estimate of utility costs: 2-bedroom \\
\hline Instant coffee (123 grams) & apartment (excl. phone) (N) \\
\hline Mineral water ( 1 liter) & \\
\hline
\end{tabular}


Electricity (monthly average family of 4) (N)

Gas (monthly average family of 4 ) (N)

Heating oil (100 liters) (N)

Water (monthly average family of 4$)(\mathrm{N})$

\section{Furnishing and household equipment (CP05)}

Batteries (two for flashlight/radio use)

Electric toaster (two toasts)

Frying pan (Teflon or good equiv.)

Insect killer spray (330 grams)

Babysitter's rate per hour $(\mathrm{N})$

Hourly rate for domestic cleaning help (N)

Maid's monthly wages (N)

(Fullime living in, but excl. the cost of keep)

Laundry detergent (4.5 kilos)

Light bulbs (2 60 watt)

Liquid dishwashing detergent $(750 \mathrm{ml})$

\section{Health (CP06)}

One x-ray at doctor's office or hospital (N)

Routine check-up at general or family doctor $(\mathrm{N})$

Visit to a dentist (N)

\section{Transport (CP07)}

Compact car

Deluxe car

Family car

Low-priced car

Annual premium for car insurance $(\mathrm{N})$

Cost of a tune-up (but no major repairs) (N)

High octane gasoline per liter

Regular gasoline

Yearly road tax or registration fee $(\mathrm{N})$

Tax, initial meter charge $(\mathrm{N})$

Tax, rate per additional kilometer $(\mathrm{N})$

Taxi ride from airport to city center $(\mathrm{N})$

Weekly car rental, lowest price (all charges included)(N)

Weekly car rental, moderate price (all charges included) (N)

\section{Communications (CP08)}

Telephone, monthly rental $(\mathrm{N})$

Telephone, charge per local call from home $(\mathrm{N})$

\section{Recreation and culture (CP09)}

Paperback novel at bookstore

Cinema ticket, 1 (N)

Compact disc album

Four best seats at cinema $(\mathrm{N})$

Four best seats at a theater or concert $(\mathrm{N})$

Purchase price of color TV set $(56 \mathrm{~cm})$

Six tennis balls

Stereo record, one long-playing

Cost of developing 36 color pictures $(\mathrm{N})$

Kodak color film (C-1359 36 exposure)

Daily newspaper

International foreign daily newspaper

International weekly newsmagazine (Time)

\section{Restaurants and hotels (CP11)}

Fast-food snack: hamburger and soft drink

Three-course dinner for four at a top restaurant $(\mathrm{N})$

Visit of four to a nightclub (including one drink per person) (N)

Two-course meal for two people $(\mathrm{N})$

One drink at bar of first-class hotel $(\mathrm{N})$

Single room with bath, one night at Hilton/ intercontinental type hotel

Same as above for moderate but comfortable hotel $(N)$

Simple meal (N)

Miscellaneous goods and services (CP12)

Soap, 1 bar bath-size

Toilet paper ( two rolls)

Aspirin (100 tablets)

Facial tissue (box of 100)

Hand lotion (125 ml)

Lipstick for women (deluxe type)

Lipstick for women (nondeluxe type)

Man's haircut (tips included) (N)

Razor blade (five pieces)

Shampoo

Toothpaste with fluoride $(120 \mathrm{~g})$

Woman's shampoo and set with tips

$(\mathrm{N})=$ denotes classification as nontraded

Source: Economist Intelligence Unit 
Table A.2 Weights used to construct the price indexes

\begin{tabular}{|c|c|c|c|c|c|c|c|c|c|c|c|}
\hline & CP01 & CP02 & CP03 & CP04 & CP05 & CP06 & CP07 & CP08 & CP09 & CP11 & CP12 \\
\hline Belgium & 18.3 & 3.4 & 7.8 & 15.0 & 8.1 & 3.2 & 14.9 & 2.3 & 11.1 & 8.3 & 7.1 \\
\hline Denmark & 16.2 & 6.0 & 6.3 & 18.3 & 7.1 & 2.6 & 16.5 & 1.9 & 11.9 & 5.4 & 7.1 \\
\hline Germany & 14.0 & 4.8 & 7.5 & 20.8 & 7.7 & 3.4 & 15.4 & 2.1 & 11.5 & 5.1 & 7.0 \\
\hline Greece & 21.1 & 5.0 & 12.3 & 9.9 & 8.1 & 4.8 & 12.8 & 2.7 & 4.3 & 11.1 & 5.7 \\
\hline Spain & 24.4 & 3.4 & 10.7 & 10.5 & 5.9 & 2.3 & 13.7 & 1.4 & 6.5 & 15.2 & 4.6 \\
\hline France & 17.0 & 4.1 & 5.9 & 15.1 & 7.2 & 3.2 & 18.0 & 2.7 & 9.3 & 8.4 & 8.6 \\
\hline Ireland & 19.0 & 9.0 & 5.3 & 8.0 & 4.5 & 2.0 & 11.8 & 1.6 & 11.4 & 19.7 & 5.8 \\
\hline Italy & 17.4 & 2.9 & 11.1 & 10.1 & 11.0 & 3.4 & 15.0 & 2.8 & 7.4 & 10.2 & 7.6 \\
\hline Luxembourg & 12.0 & 10.1 & 7.6 & 11.0 & 10.8 & 1.4 & 19.2 & 1.3 & 11.0 & 9.6 & 5.9 \\
\hline Netherlands & 15.8 & 5.0 & 6.7 & 19.4 & 9.2 & 2.2 & 13.5 & 2.0 & 12.1 & 7.2 & 5.3 \\
\hline Austria & 13.1 & 4.0 & 8.3 & 13.9 & 9.0 & 1.9 & 14.5 & 3.2 & 11.6 & 14.3 & 5.4 \\
\hline Portugal & 21.6 & 3.3 & 7.0 & 9.3 & 7.9 & 5.7 & 20.5 & 2.1 & 3.9 & 13.1 & 3.9 \\
\hline Finland & 17.3 & 7.3 & 5.4 & 15.8 & 5.1 & 4.5 & 16.3 & 2.4 & 11.5 & 9.4 & 4.7 \\
\hline Sweden & 15.7 & 5.3 & 7.3 & 19.5 & 5.8 & 3.0 & 15.8 & 3.6 & 11.4 & 6.4 & 6.0 \\
\hline United Kingdom & 12.1 & 5.7 & 7.0 & 11.8 & 7.8 & 1.4 & 16.1 & 2.5 & 14.9 & 13.7 & 5.7 \\
\hline Norway & 14.1 & 3.0 & 6.9 & 16.4 & 7.5 & 2.7 & 22.3 & 2.1 & 13.6 & 4.5 & 5.6 \\
\hline
\end{tabular}

Note: See table A.1 for a list of the categories. None of the items in our sample was assigned to category CP10, Education, whose weight is 0.9 percent in the euro area as a whole. 


\section{WORKING PAPERS}

No. 94-1.

No. 94-2.

No. 94-3.

No. 94-4.

No. 94-5.

No. 95-1.

No. 95-2.

No. 95-3.

No. 95-4.

No. 95-5.

No. 95-6.

No. 96-1.

No. 96-2.

No. 96-3.

No. 96-4.

No. 96-5.

No. 96-6.

No. 96-7.

No. 96-8.

No. 96-9.

No. 96-10.

No. 96-11.

No. 96-12.

No. 96-13.

No. 96-14.

No. 96-15.

No. 97-1.

No. 97-2.

No. 97-3.

No. 97-4.

No. 97-5.

No. 98-1.

No. 98-2.

No. 98-3.

No. 98-4.
Jeffrey A. Frankel with Shang-Jin Wei and Ernesto Stein, “APEC and Regional Trading Arrangements in the Pacific"

Edward M. Graham, "Towards an Asia Pacific Investment Code"

Paul Wonnacott, "Merchandise Trade in the APEC Region: Is There Scope for Liberalization on an MFN Basis?"

Paul Wonnacott, "The Automotive Industry in Southeast Asia: Can Protection Be Made Less Costly?"

Marcus Noland, "Implications of Asian Economic Growth"

C. Fred Bergsten, "APEC: The Bogor Declaration and the Path Ahead"

Jeffrey J. Schott, "From Bogor to Miami . . . and Beyond: Regionalism in the Asia Pacific and the Western Hemisphere"

Marcus Noland, "Has Asian Export Performance Been Unique?"

Gautam Jaggi, "Association of Southeast Asian Nations (ASEAN) and ASEAN Free Trade Area (AFTA): Chronology and Statistics"

Marcus Noland, "The North Korean Economy"

Marcus Noland, "China and the International Economic System"

C. Fred Bergsten, "APEC after Osaka: Toward Free Trade by 2010/2020"

Marcus Noland, "Public Policy, Private Preferences, and the Japanese Trade Pattern"

Marcus Noland, "German Lessons for Korea: The Economics of Unification"

Marcus Noland, "Research and Development Activities and Trade Specialization in Japan"

Gautam Jaggi, Mary Rundle, Daniel Rosen, and Yuichi Takahashi, "China's Economic Reforms: Chronology and Statistics"

Marcus Noland, "US-China Economic Relations"

Raymond Atje and Gary Hufbauer, "The Market Structure Benefits of Trade and Investment Liberalization"

Marcus Noland, "The Future of US-Korea Economic Relations"

Edward M. Graham, "Competition Policies in the Dynamic Industrializing Economies: The Case of China, Korea, and Chinese Taipei”

Marcus Noland, Sherman Robinson, and Monica Scatasta, "Modeling Economic Reform in North Korea"

Marcus Noland, "Trade, Investment, and Economic Conflict between the US and Asia"

C. Fred Bergsten, "APEC in 1996 and Beyond: The Subic Summit"

Marcus Noland, "Some Unpleasant Arithmetic Concerning Unification"

Marcus Noland, "Restructuring Korea's Financial Sector for Greater Competitiveness"

C. Fred Bergsten, "Competitive Liberalization and Global Free Trade: A Vision for the 21st Century"

Marcus Noland, "Chasing Phantoms: The Political Economy of USTR"

Jacqueline McFadyen, "U.S.-Japan Civil Aviation: Prospects for Progress"

C. Fred Bergsten, "Open Regionalism"

Adam S. Posen, "Lessons from the Bundesbank on the Occasion of Its 40th (and Second to Last?) Birthday"

Marcus Noland, Sherman Robinson, and Li-Gang Liu, "The Economics of Korean Unification"

Marcus Noland, Sherman Robinson, and Li-Gang Liu, "The Costs and Benefits of Korean Unification"

Li-Gang Liu, Marcus Noland, Sherman Robinson, and Zhi Wang, "Asian Competitive Devaluations"

C. Fred Bergsten, "Fifty Years of the GATT/WTO: Lessons from the Past for Strategies for the Future"

Jacqueline McFadyen, "NAFTA Supplemental Agreements: Four Year Review" 
No. 98-5.

No. 98-6.

No. 99-1.

No. 99-2.

No. 99-3.

No. 99-4.

No. 99-5.

No. 99-6.

No. 99-7.

No. 99-8.

No. 99-9.

No. 99-10.

No. 99-11.

No. 99-12.

No. 00-1.

No. 00-2.

No. 00-3.

No. 00-4.

No. 00-5.

No. 00-6.

No. 00-7.

No. 00-8.

No. 00-9.

No. 01-1.
Hiroko Ishii and Erika Wada, "Local Government Spending: Solving the Mystery of Japanese Fiscal Packages"

Marcus Noland, Sherman Robinson, and Zhi Wang, "The Global Economic Effects of the Japanese Crisis"

Marcus Noland, Sherman Robinson, and Tao Wang, "Rigorous Speculation: The Collapse and Revival of the North Korean Economy"

Marcus Noland, Sherman Robinson, and Tao Wang, "Famine in North Korea: Causes and Cures"

Marcus Noland, "Competition Policy and FDI: A Solution in Search of a Problem?"

Marcus Noland, Sherman Robinson, and Zhi Wang, "The Continuing Asian Financial Crisis: Global Adjustment and Trade"

Adam S. Posen, "Why EMU Is Irrelevant for the German Economy"

C. Fred Bergsten, "The Global Trading System and the Developing Countries in 2000"

Marcus Noland, Sherman Robinson, and Tao Wang, "Modeling Korean Unification"

Marcus Miller and Lei Zhang, "Sovereign Liquidity Crisis: The Strategic Case for a Payments Standstill"

C. Fred Bergsten, Olivier Davanne, and Pierre Jacquet, "The Case for Joint Management of Exchange Rate Flexibility"

Kenneth N. Kuttner and Adam S. Posen, "Does Talk Matter After All? Inflation Targeting and Central Bank Behavior"

Gary Clyde Hufbauer and Erika Wada, "Hazards and Precautions: Tales of International Finance"

Gary Clyde Hufbauer and Tony Warren, "The Globalization of Services: What Has Happened? What Are the Implications?"

Keith Maskus, "Regulatory Standards in the WTO: Comparing Intellectual Property Rights with Competition Policy, Environmental Protection, and Core Labor Standards"

Richard M. Goodman and John M. Frost, "International Economic Agreements and the Constitution"

Catherine L. Mann, "Electronic Commerce in Developing Countries: Issues for Domestic Policy and WTO Negotiations"

C. Fred Bergsten, "The New Asian Challenge"

Marcus Noland, "How the Sick Man Avoided Pneumonia: The Philippines in the Asian Financial Crisis"

Kenneth N. Kuttner and Adam S. Posen, "Inflation, Monetary Transparency, and G3 Exchange Rate Volatility"

Catherine L. Mann, "Transatlantic Issues in Electronic Commerce"

Morris Goldstein, "Strengthening the International Financial Architecture: Where Do We Stand?"

Marcel Fratzscher, "On Currency Crises and Contagion"

John H. Rogers, Gary Clyde Hufbauer, and Erika Wada, "Price Level Convergence and Inflation in Europe"

Working Papers are only available directly from the Institute (not from our international distributor or bookstores). Most appear in full form on our Web site at http://www.iie.com/catalog/wp/apecwp.htm. If you require a paper that is not available on the Web site, please contact us.

Working Papers

Tel: (202) 328-9000

Fax: (202) 328-5432

http://www.iie.com
Institute for International Economics

11 Dupont Circle, NW, Suite 620

Washington, DC 20036-1207 